Original Article (short paper)

\title{
Reasons for women's approach and permanence in Zumba
}

\author{
Carina Bianca de Menezes Nascimento ${ }^{1}$ (1) , Rogério Cruz de Oliveira ${ }^{1,2}$ (1) \\ ${ }^{1}$ Prefeitura Municipal de Bertioga, Grupo de Estudo e Pesquisa Sociocultural em Educação \\ Física, Santos, SP, Brasil, ' ${ }^{2}$ nniversidade Federal de São Paulo, Campus Baixada Santista, \\ Departamento de Ciências do Movimento Humano, Programa de Pós-graduação Interdisciplinar em \\ Ciências da Saúde, Grupo de Estudo e Pesquisa Sociocultural em Educação Física, Santos, SP, Brasil.
}

Editor: Angelina Zanesco. UNESP/Rio Claro, SP, Brasil.

\begin{abstract}
Aim: This study aims to comprehend the reasons for women's approach and permanence in Zumba. Method: In this descriptive study, we interviewed 20 female interviewees 31-66 years-old ( $\mathrm{M}=46.14 ; \mathrm{SD}=10,07)$. Inclusion criteria were: have been training Zumba for at least one year and with a minimum frequency of once a week. We excluded women who practice other activities simultaneously to Zumba. For data collection, we applied a semi-structured interview covering the following aspects: how they approached Zumba and the reasons why they kept training it. Data analysis was performed using non-aprioristic categories. Results: The interviewees reported approaching Zumba by friends, family, personal initiative, media, and medical advice. The permanence in the modality was related to therapeutic aspects, pleasure, sociability, being good for health, and engagement in a body practice. Conclusion: We concluded that women approach and keep training Zumba for reasons that surpass the physical benefits provided by body practices; rather, it is deemed as a useful and social practice.
\end{abstract}

Keywords: health promotion; body practice; dance.

\section{Introduction}

Zumba Fitness LCC was founded in 2001 by the Colombian choreographer Alberto "Beto" Perez, together with the two American entrepreneurs Alberto Perlman and Alberto Aghion'. Zumba was developed in the mid-1990s. Before beginning a gymnastics localized workout class, the choreographer noticed that he had forgotten his $\mathrm{CD}$, and improvised a choreography using Latin rhythms ${ }^{1}$.

Its movements are inspired by Latin American rhythms, such as salsa, samba, merengue, and reggaeton. Practitioners perform basic aerobic steps and are free to move and join uncomplicated choreographies. There is no right or wrong; each person follows a personal time and rhythm, and no specific skills to dance are required ${ }^{2}$.

According to Ferreira ${ }^{3}$, Alberto Perlman suggested the term Zumba merges the names Samba and Rumba, which for him translates into the party. Krishnan et al. ${ }^{4}$ state that Zumba has reached popularity among women for being interactive and enjoyable, which motivates its practitioners to engage in it.

For Oliveira and Alvarez ${ }^{5}$, the reasons for approaching and keep dancing Zumba are its uncomplicated choreographies and promoted well-being and teacher's good performance. According to Ferreira ${ }^{3}$, Zumba being depicted as a dance invested with a free form contributes to its popularity.

In April 2014, during an online interview conducted by the journalist Romana Borja-Santos, the choreographer Beto Perez used the following expression when addressing the quality of life and well-being that Zumba provides: "People do not enjoy exercising, but they do enjoy partying. They do not have time to go to the gym, but they do have time to go to parties. We have brought the party into the gyms and captivated them all. Zumba has become a philosophy of life because life is a celebration."

Thus, it is possible to comprehend some differences between Zumba and other exercises programs regarding adherence: popularity; no specifics skills, and; party atmosphere. However, health benefits, including strength, endurance, balance, stress reduction, and so on, should be considered as well.

"Insofar as dance steps increase heart rate, providing cardiovascular exercise, exercise variations enable muscle training" (p.10) $)^{3}$. Still, according to Ferreira ${ }^{3}$, this results from the sum of choreography and exercise movements, which engages a greater muscular endurance and consumes energy from aerobic and anaerobic pathways in sequenced movements.

Ljubojević, Jakovljević, and Poprzen ${ }^{2}$ frame this modality within those that present significant effects on the body composition by playing a role in reducing weight, body fat percentage, and mass of fat. Regarding the rhythms contemplated by Zumba, the authors ${ }^{2}$ stress that the associations between the basic principles of aerobic physical training and strengthening increase energy expenditure, improve posture, cardiovascular system, and physical fitness, and strengthens the osteomyoarticular system.

A study ${ }^{6}$ - aimed at understanding the impact of Zumba classes in the health and well-being of peripheral communities of the municipality of Petrolina/PE - showed that participants' anxiety level reduced $20 \%$ after a 20 -minute Zumba class. This study also observed that class joy played a positive role for participants. 
During an Extension Project of the Universidade Federal do Rio Grande do Norte, Araújo et al. ${ }^{7}$ performed a study with a group of 16 women, stressing aspects related to training Zumba and the stimuli and effects arising from dancing.

Dance is an engaging and pleasant form of physical activity; when performed in a group, it becomes even more attractive and dynamic for its joint movements and the exchange of bonds and experiences. It is beneficial for the human body in boosting exercise motivation, attention, and cognitive ability (for increasing both neural connections and blood flow), as well as lifting the mood. It also integrates balance, coordination, strength, flexibility, aerobic capacity, and proprioception training. Besides all of that, dance also stimulates auditory, visual, sensory, and motor learning - everything within a single learning environment that yields pliability ${ }^{7}$ (p. 267).

According to Donath et al. ${ }^{8}$, the set of components presents in Zumba (balance, endurance, and strength) make adherents grow all over the world.

Given above, we understand Zumba as an emerging body practice in the contemporary context that requires further studies with different deployments, including the path for the approach and permanence in this "party atmosphere" provide by Zumba classes.

In this sense, this study aims to comprehend the reasons for women's approach and permanence in Zumba.

If the body practices can be understood as a cultural manifestation unveiled in body dynamics ${ }^{9}$, our study has the intention to reveal this particular scenario. From Geertz ${ }^{10}$ perspective, the culture is public because meaning is public. This is the background to our manuscript.

\section{Method}

This study was submitted and approved by the Research Ethics Committee of the Universidade Federal de São Paulo (UNIFESP) according to the opinion N. 1081/2018 and in its development. In addition, it was reviewed and approved by a Research Ethics Committee before starting the study, and participants must provide written informed consent as stated by the Brazilian Council of Ethics in research with the human subject (CONEP/BR).

This study comprises descriptive research - the type of study that writes the facts and phenomena of a given reality ${ }^{11}$. It adopts the qualitative approach described by Minayo ${ }^{12}$, which tackles specific questions and is concerned about a level of reality that cannot be quantified.

Twenty female interviewees $31-66$ years-old ( $M=46.14$; $\mathrm{SD}=10.07$ ) were included considering the following inclusion criteria:
- They must have been Zumba practitioners for at least 1 year; and

- They must practice it at a minimum frequency of once a week.

The following was considered an exclusion criterion:

- Women practicing other activities simultaneously to Zumba;

The recruitment of interviewees took place in January and February in 2019 in the context of one studio dance from a municipality in the Baixada Santista region - São Paulo State (Brazil), after approval by the owner. Twenty women were engaged in the same Zumba class group. In this sense, the age range of this sample does not consist of a bias. The data from this particular context are culturally significant since culture is collective as well.

For data collection, we performed semi-structured interviews. For Triviños ${ }^{11}$, this method stems from certain basic questions, supported by a theoretical framework, which enable the researcher to obtain answers that clarify the study issue. The interview addressed questions on how interviewees approached Zumba and the reasons why they kept practicing it. This script was followed in all interviews, and the answers were recorded for data analysis. In addition, it was collected general data about the profile of interviewees: age, years' Zumba experience, occupation, and frequency. To protect anonymity we adopted nicknames for each interviewee.

In addition, the data were collected between January and February in 2019, and all the interviews were face-to-face at the studio dance at times previously agreed upon - before Zumba classes. All the interviews were performed by the first author.

Data analysis considered the transcript content of the interviews. We considered non-aprioristic categories for analyzing the answers. According to Campos13, such categories are elaborated in contact with the analyzed material, either by frequency (for this study, answers with common arguments) or by implicit relevance (relevant arguments to the study issue). In this method, each interviewee's answer may be analyzed in two or more categories.

This article reports part of the results of a master's thesis.

\section{Results}

The results indicated that the sample was majority characterized by middle-adulthood experienced in Zumba' practice, and various occupations, mainly lawyers, teachers, and retired (Chart 1). Also, 65\% of interviewees were engaged in the Zumba classes two times per week and 35\% four or more times. This data suggests that these women were physically actives.

Chart 1 - Profile of interviewees.

\begin{tabular}{ccccc}
\hline Nickname & $\begin{array}{c}\text { Age } \\
(\mathbf{M = 4 6 . 1 4} \text {; SD: 10.07) }\end{array}$ & $\begin{array}{c}\text { Years' Zumba experience } \\
(\mathbf{M}=\mathbf{4 . 3 6} \text {; } \mathbf{S}=\mathbf{2 . 2 4})\end{array}$ & Occupation & Weekly frequency \\
\hline CIDA & 66 & 8 & Retired \\
DORA & 47 & 5 & Lawyer & 4 \\
PATY & 47 & 8 & Nurse
\end{tabular}




$\begin{array}{ccccc}\text { ALBA } & 58 & 5 & \text { Housewife and manicure } & 4 \\ \text { FAFÁ } & 64 & 6 & \text { Retired } & 2 \\ \text { ZITA } & 64 & 8 & \text { Retired } & 4 \\ \text { LENA } & 49 & 2,5 & \text { Lawyer and craftswoman } & 2 \\ \text { SOL } & 52 & 6 & \text { Retired } & 2 \\ \text { LUNA } & 44 & 1 & \text { Administrative assistant } & 2 \\ \text { VIVI } & 47 & 1 & \text { Teacher } & 2 \\ \text { ROSE } & 53 & 6 & \text { Laboratory assistant } & 6 \\ \text { GINA } & 61 & 6 & \text { Lawyer } & 2 \\ \text { LULI } & 38 & 5 & \text { Lawan resources analyst } & 2 \\ \text { RAFA } & 35 & 3 & \text { Housekeeper } & 2 \\ \text { CLARA } & 43 & 5 & \text { Civil Servant } & 2 \\ \text { BIA } & 41 & 5 & \text { Lawyer /Civil Servant } & 4 \\ \text { MARA } & 31 & 2 & \text { Teacher } & 2 \\ \text { PAULA } & 36 & 3 & \text { Teacher } & \end{array}$

Figure 1 shows that friends or family, and personal initiative are the main reasons to approach to Zumba practices. This finding was interesting since social media has a significant impact on modern life.

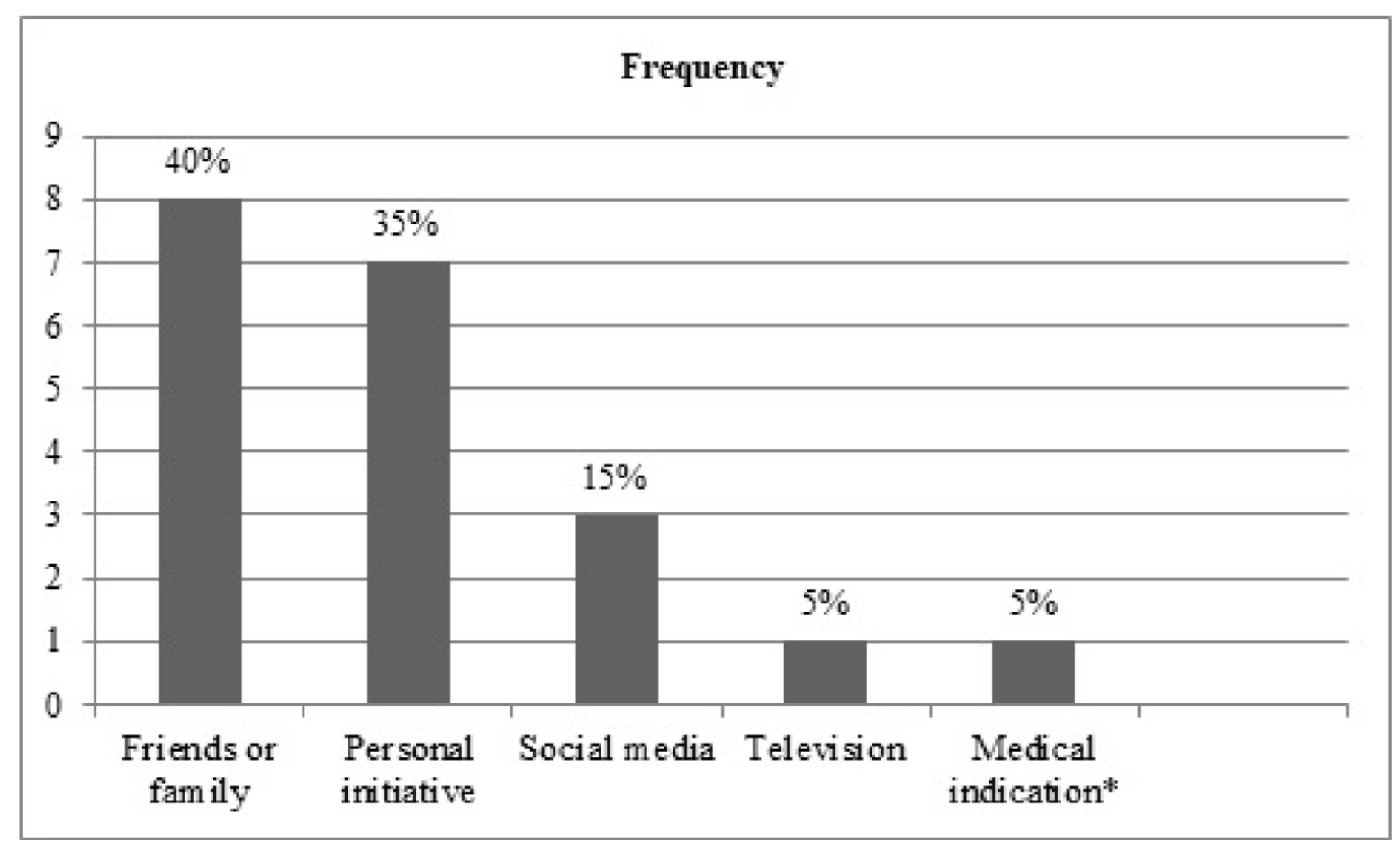

Figure 1 - Approach reason

Source: study data.

Note: * The interviewee Zita underwent heart surgery after suffering a heart attack. The doctor indicated practicing Zumba and walking for, according to the interviewee, "[...] accelerating heart pathways." She preferred Zumba for being a fixed commitment. 
Figure 2 displays that therapy and pleasure were embedded in 18 of 20 interviewees' speech. Here, it drew attention that the physical benefits did not focus on the interviewee.

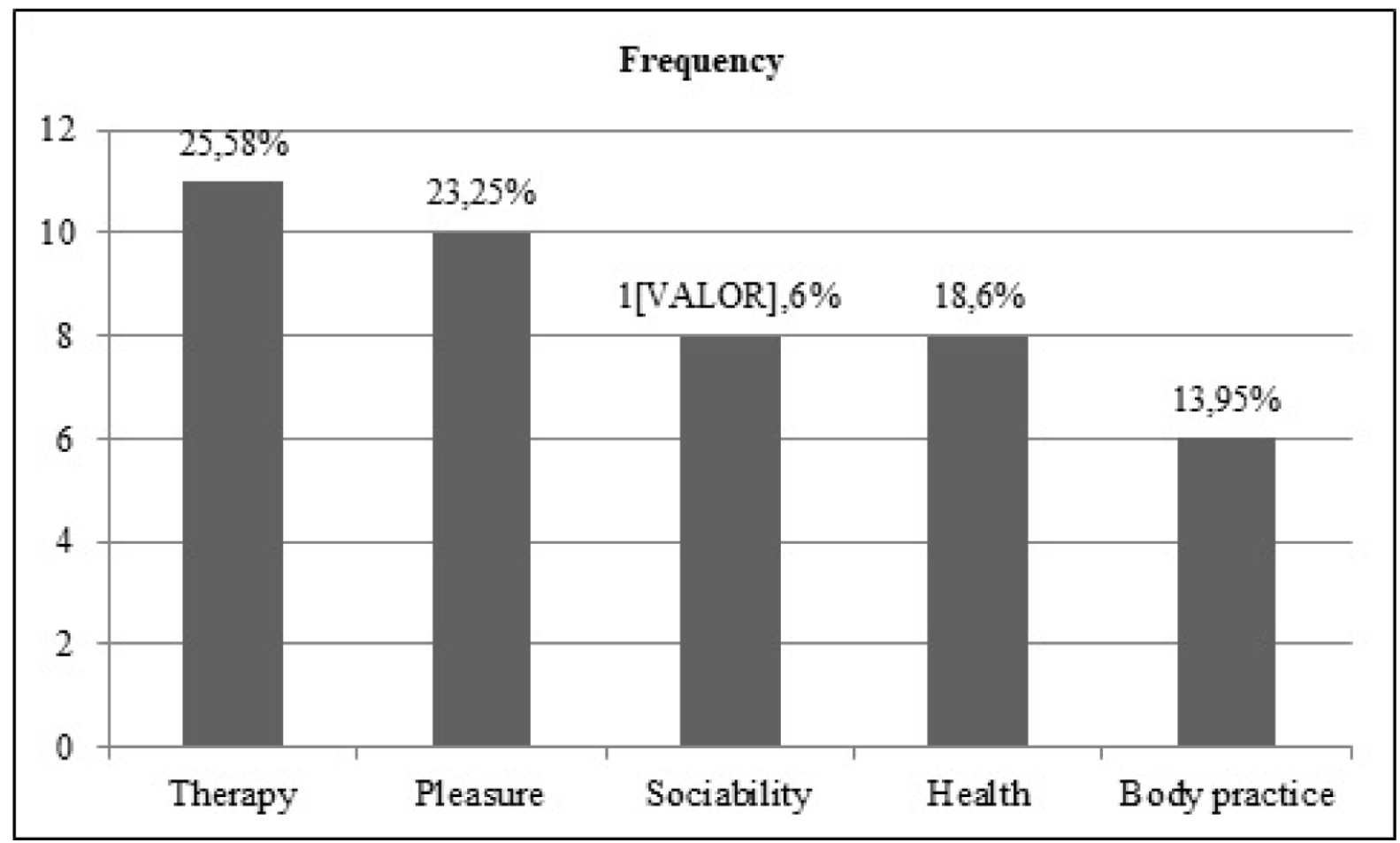

Figure 2 - Permanence reason*

Source: study data.

Note: * In this variable, each interviewee's answer could have been analyzed in two or more categories. In this case, we obtained 43 analytical frequencies in 20 interviewees.

In "Therapy," 11 interviewees reported keeping practicing Zumba because they feel good during classes.

"For me, I think it's good for my head, ah... it's good for my health, I feel in high spirits. Yeah... it logically has this physical issue, it's emotional because I think the dance engaged my emotional side." (Dora)

"Ah... because it irons out the stress of our daily lives. Because when you're doing an activity you don't worry about those problems that we have, right?" (Zita)

"[...] it lifts my spirits... but most importantly, for me, Zumba dance is like this: it lifts my spirits, keeps me more cheerful." (Lena)

"Firstly because I enjoyed the pleasure of being here: the songs, this cheerful mood [...]." (Vivi)

"It relieves stress. [...] When you come here, it looks like you have left all your problems outside. While you are inside ... it flashes in your mind like a movie that you're there just to relax. It's like this: the music, the atmosphere, the people in the environment, they are so receptive, I feel very good, very welcome." (Luna)

"So you're singing, dancing, relaxing and doing different things [...] You throw yourself, you let go, you laugh, you dance, you sing. [...] In my case, it was something like a therapy." (Rose)
"Oh, I guess it's not only one thing. I think there are various factors, just like I said. ..., you feel happier, you release the hormones of happiness and it's music. It's fun [...]." (Gina)

"The well-being it promotes. Not only physical but mental as well. Because, for me, Zumba is not just an activity, it's like therapy." (Bia)

"[...] because it relieves stress, it really does relieve stress. So, coming here, for me, it's a therapy." (Mara)

"Everything makes me keep coming [...] My well-being, my willpower, I think it nourished my self-esteem, improved my overall well-being." (Carol)

"[...] plays a role in my well-being. It brightens my mood, my spirit, my weight." (Luana)

In "pleasure," 10 interviewees recognized the importance of performing an activity in which they feel pleasure.

"What makes me keep practicing, is that Zumba is all the best for everyone. In my opinion, [...] it comprises exercises within dance, so, for example, for me, who likes dancing, it's great, because I take the opportunity to cool off, unwind. It's good for the body, for the mind. You free yourself, you end up seeing yourself more beautiful [...]." (Cida)

“[...] because I do enjoy the dance. It's diverse, not just focused 
on a single style of music. So the songs, especially the Latin ones, draw a lot of my attention. The Latin ones, the country, are the ones I like the most." (Paty)

"[...] so, I feel really good when I'm dancing, taking classes, I love the class, the dance [...]" (Alba)

"At first it started as a physical exercise, a way of practicing a physical exercise that would give me pleasure. And then, for the pleasure of dancing." (Fafá)

"Because I enjoy it. I've always liked to dance. [...] So here's kind of, a way to distract myself, to speak, to talk to one, to another. For me, Zumba is excellent." (Zita)

"Firstly, because I have always enjoyed performing an aerobic dancing activity [...] because dance replaces a treadmill, a race and you do the aerobic part with pleasure [...]." (Sun)

"First, enjoying it, right? I believe that everything we enjoy doing, we do well. And we are motivated, we want to continue doing it." (Luna)

"[...] anyway, and the feeling of joy is great. I started practicing Zumba two to three times a week and got to a point that I started practicing every day: from Monday to Friday, including Saturday." (Luli)

"It is something I found myself with. I like it a lot, and I think it's a very tasty sport. It's not something I go because I have to, I go happy, I go light [...]." (Rafa)

"I like the stimuli the teachers give us, I like the environment, I like the songs - all of it attracts me." (Carol)

Regarding "Sociability," 8 interviewees reported that the reason why they keep practicing Zumba is due to social integration and interaction with friends.

"[...] and besides everything, it brought me friendships, yeah... then, it was the combination of many things: health, a physical issue, mental issue, and relationship with other people." (Dora)

"[...] but the key factor is that I think there is something extra in Studio Dance. It is a force, not only dance, which already impacts a lot on me. Is that union of people, and the engagement that we have in being there not only for the dance. It is as if we were family." (Paty)

"We also socialize, right? This is also part of it. Especially when you're retired, you don't have those groups anymore, right? Where you work, when you're on the street. So for me it supplemented." (Fafá)

"[...] besides people, the joy it brings, because I like dancing [...] because then you start clinging to that group that makes you feel well, the company [...]." (Rose)

"[...] I love it. There are also the friendships. You end up making friends, you have contact with those people every day. Then you end up identifying with some people more, other people less." (Gina)

"Besides integrating with other people, Zumba brought me joy." (Luli)
"I like dancing, I like friendships, I like the environment. It makes me good, it gives me harmony. I like it. That's why I keep going." (Carol)

"Doing an aerobic exercise, together with your friends, with nice people, contributes even ifjust a little. Because I am not such a regular practitioner [...]." (Luana)

Regarding "Health," 8 interviewees reported health improvement.

"For my health, and I felt very good too, right? Because then I don't just stand still." (Alba)

"[...] because of the metabolism. I have seen that practicing this exercise helps a lot to lower my cholesterol, triglycerides and everything... the overall metabolism." (Fafá)

"Also because of health. I realized that by practicing this activity I lost way more weight. Because it came to the point in which two years ago I was weighing $120 \mathrm{~kg}$, and nowadays I'm weighing $88 \mathrm{~kg} . "($ Luna)

"It has improved both my physical and emotional health. I have gone through a small depressive episode, and it [Zumba] helped me a lot to overcome it. I did not need any medication to overcome it. I lost $20 \mathrm{~kg}$ healthily and, finally, today I cannot imagine myself without it." (Luli)

"In my case, it has changed everything: the body, the mind; it was good for the body and the mind. I've lost weight. Because it changes your mood. It changes everything. You live a lightweight life when you dance." (Rafa)

"It's as if it relieves my stress [...] This is why it is good for my health. For both sides: physical, because I feel more willing, and the mental part too." (Bia)

"At first, It's good for the physical benefit of maintaining health: I've had better levels on my blood tests." (Mara)

"It's indeed the benefits it brings to health, and even to my body. Ever since I started, I adopted a more regulated diet, fixed times to perform physical activity." (Paula)

As for "Body practice ${ }^{[1]}$," 6 interviewees reported being frequent to Zumba for being engaged within a body practice.

"[...] and by doing this exercise, I got excited and starter undertaking other monitorings. But I have also started eating less, drinking a lot of water, and practicing Zumba. I lost 19.8kg." (Cida)

“[...] It also increases my flexibility... what else can I tell you?! Yeah... mobility [...]." (Lena)

"[...] resistance! Because I feel that I have more resistance in doing things. More willingness in everyday life [...]." (Vivi)

"First of all, due to the physical activity, the aerobic activity you practice, your body conditioning increases, you feel more willing." (Gina)

"I practice Zumba for the body. Like, to circulate the blood. I don't care that much about losing weight. But I believe it's important performing a physical activity for the body." (Clara)

“Doing an Aerobic Exercise." (Luana) 


\section{Discussion}

According to Silva, Medeiros, and Marchi Júnior ${ }^{14}$, choosing and approaching dance modalities rely upon family influence, as the practice is responsible for promoting health. Such a premise is corroborated by our study: the strongest reason for approaching Zumba was close to social networks - friends and family. The approach was also widely motivated by personal initiative, which also mirrors Campos ${ }^{15}$, when stated that individuals need to act through their own life. Hence, it can mean that people, especially women, are nearby each other. In this case - Zumba classes - we believe that party atmosphere foments the approach.

We also observed media influence on women's approaching Zumba (social network and television). Historically, the media has been allied with body practices; be it from its massification as a product to be consumed (discussed in depth by Baptista ${ }^{16}$ ), or from its disclosure, which allows people's approach, as stated by Mantovani ${ }^{17}$. According to Figueira Júnior ${ }^{18}$, television as an opinion-maker may foster a healthy lifestyle. For understanding that health is neither a style nor an option, we do not endorse this last premise. Yet, the media interferes in people's choice and approach towards body practices, corroborating our study findings, even though the interviewees' answers have shown low frequency (in this category).

Medical advice as a reason for approaching body practices is not a novel issue and has been previously addressed by Zita. According to $\mathrm{Fraga}^{19}$, since the 1970 s, there is a causation relationship between aerobic exercises and health in Brazil, which is influenced by Kenneth Cooper. Based on a didactic approach, Fraga $^{19}$ states that this initial movement has culminated in the contemporary order "moving is needed" - an allusion to "Agita [Move] São Paulo," a program developed in 1996 by the Center of Studies of the Physical Fitness Laboratory of São Caetano do Sul (CELAFISCS) in agreement with the Health Department of the State of São Paulo. Some medical guidelines suggest adopting a body practice; the "South American Guidelines for Cardiovascular Diseases Prevention and Rehabilitation," for example, recommends walking, dancing, cycling, and swimming for cardiac rehabilitation in women ${ }^{20}$, which stress the coherence in understanding Zita's medical advice for Zumba.

Regarding permanence, the interviewees showed concern with their health. In this sense, healthy eating, self-care, physical activity practice, well-being, quality of life, and so on, were mentioned as a path to have a better life and health condition as well. According to our data, Zumba classes helped them seeking these changes; therefore, permanence was reinforced.

Alves and Nascimento ${ }^{6}$ conducted a study on the impact of Zumba on health and well-being, in which they observed that the main reason for choosing a body practice is the after-class feeling of well-being, followed by the contagious joy and the stimuli provided by the instructors, as well as social interaction, body work, and caloric burning. This emphasizes the diversity of agents influencing the permanence of students in Zumba classes.

Our interviewees considered Zumba as a therapy in which they can unwind and relax from their daily lives and health issues, which plays a significant role in their well-being. Koch, Morlinghaus, and Fuchs ${ }^{21}$ conducted a study with 31 patients of the Psychiatric University Clinic in Heidelberg, Germany, in which they analyzed dance as therapy and found that it significantly decreases depression and increases patients' vitality. These findings also were presented in our study, for instance when Dora mentioned her emotional side improvement; Zita forgot the problems; Luna and Mara relieved the stress, and; Luana enhanced her mood. Thus, we believe that dance is part of this process, in a way, by promoting them space to acknowledge what they can do by themselves.

Moreover, Carvalho and Mendes ${ }^{22}$ define body practices as conditioning factors of healthy behaviors, as it enables encounters, motivates the practice of care, and fosters reflection upon yourself. According to them, body practices also mirror an individual's way of living in our current society.

Santos and Knijnik ${ }^{23}$ report that the reasons for engaging in regular physical activities and a healthier lifestyle in middle-adulthood (40-60 years) are associated with medical advice and/or prescription, aesthetics, leisure/quality of life, among others. However, the pleasure experienced by the practice is determinant for influencing and motivating their permanence in it.

Antunes and Schneider ${ }^{24}$ relate body practices to sociability and pleasure. Likewise, our study reported keeping practicing Zumba for the same reasons, which they consider important for their health. To half interviewees (Cida, Paty, Alba, Fafá, Zita, Sol, Luna, Luli, Rafa, and Carol) dancing is related to happiness, fun, dissipation, and freedom (i.e. the feeling of pleasure in Zumba classes). By studying the health promotion and quality of life proportionate by body practices among older people, Toldrá et al. ${ }^{25}$ acknowledge them as beneficial for physical, mental, and emotional health, besides preventing diseases.

Domene et al. ${ }^{26}$ conducted a study on the effects of Zumba in physiological, mental, and psychosocial health, and found that dance plays a role in health promotion, reporting improvements in the quality of life of adults.

Regarding ageing, Toldrá et al. ${ }^{25}$ state that body practices may prevent or even eliminate health risks for comprising beneficial habits that provide longer and better life. They also stress that an individual's quality of life is intrinsically related to his/her lifestyle. Our study did not focus on ageing; yet, four of our female interviewees were over 60 years, which enable us to understand how pertinent these observations are.

$\mathrm{Pich}^{27}$ addresses another issue mentioned by our interviewees: socialization. The author point that in relating to the other we are caring for ourselves - one is enough in oneself, individuals need to exchange experiences, listen, be affected by other people. We understand that body practices may be intertwined with the experiences and subjectivities of the individual in self-practice. In this sense, the sociability opened the opportunities for friendship anew (Fafá, Gina, and Dora), being a part of a new family (Paty) and finding/enjoying happiness (Luli).

On the other hand, dancing allows us (by body movements) to understand and be sensitive towards the external world and our inner self, promoting health ${ }^{28}$. In our study, health promotion was related to Zumba from self-perception.

For Abrão and Pedrão ${ }^{29}$, we acquire by dancing a better understanding of everything within the environment, and sensitivity and refinement of our senses of vision, hearing, and 
kinesthetic. By awakening such senses, dance intensely acts on our emotions, exercising our trust and safety towards ourselves.

On the other hand, Matos $^{30}$ stresses how economic conditions are the most impact on health care. It means that the sedentariness should not be faced as a lack of strength of will only or another one superficial issue. The engagement with body practices (Zumba or another one) is also linked with various conditions, including financial, corroborating our study data because all interviewees have paid by Zumba classes.

These findings were noticed in various age groups in our study. However, it is noteworthy how meanings were perceived in interviewees experienced in Zumba classes (e.g. 8 practice years) as far as beginners.

Overall, the data have shown that women approached Zumba through their small social circle (friends and family), and empowerment, but their permanence took place by a wide social circle (new group, new friends, a weekly commitment, and so on) as well as the classical issues relating to health promotion, well-being, and functional organic benefits. Thus, the findings suggest that the party atmosphere experienced by Zumba practitioners is the differential as a body practice and the key of the permanence as well.

\section{Conclusion}

Women approached and kept training Zumba for reasons that surpass the physical benefits provided by body practices; it is rather deemed as a useful and social practice. Our results oppose the contemporary demands for burning more calories (usefulness) rather than worrying about sociability and encounter (social practice), as stated by Fraga ${ }^{19}$. Our data affirms that Zumba - although a trademark - enables its practitioners to feel good and cherish group involvement.

Yet, the data should be read with caution: they were analyzed and developed within a private context (studio dance), and our study group is apart from vulnerability issues. This study aims to corroborate the theme of body practices, dance, and health promotion, and certainly can guide and expand other debates within this same path.

\section{Endnotes}

${ }^{[1]}$ We understand that body practice, as proposed by Lazzarotti Filho et al. ${ }^{9}$, embraces both the terms "physical exercise" and/ or "physical activity," used by the interviewees.

\section{References}

1. Luettgen M, Foster C, Doberstein S, Mikat R, Porcari J. Zumba ${ }^{\circledR}$ : Is the "fitness-party" a good workout? J Sport Sci Med. 2012; 11(2): 357-358.

2. Ljubojevic A, Jakovljevic V, Poprzen M. Effects of zumbaZumbaess program on body composition of women. SportLogia. 2014; 10(1): 29-33.
3. Ferreira J. Caracterização da intensidade de esforço de uma aula de Zumba ${ }^{\circledR}$ Fitness. Porto. Dissertação [Atividade física e saúde] - Universidade do Porto; 2014.

4. Krishnan S, Tokar TN, Boylan MM, Griffin K, Feng D, McMurry L et al. Zumba ${ }^{\circledR}$ Dance Improves Health in Overweight/Obese or Type 2 Diabetic Women. Am J Health Behav. 2015; 39(1): 109-120.

5. Oliveira MF, Alvarez BR. Fatores motivacionais para a adesão e aderência nas aulas de zumba fitness em academias das microrregiões de Criciúma e Araranguá. EFDeportes. 2014; 19(195):1-1.

6. Alvez JN, Nascimento DC. Dança de Zumba como Instrumento em prol da Saúde e do Bem-estar para comunidades periféricas do Município. Id on Line Rev. Mult. Psic. 2016; 10(30): 7-15.

7. Araújo JTM, Rocha CF, Farias GMC, Cruz RS, Assunção Júnior JC, Silva HJA et al . Experiência de mulheres com fibromialgia que praticam zumba. Relato de casos. Rev. dor. 2017; 18(3): 266-269.

8. Donath L, Roth R, Hohn Y, Zahner L, Faude O. The effects of Zumba training on cardiovascular and neuromuscular function in female college students. Eur. J. Sports Sci. 2014; 14(6): 569-577.

9. Lazzarotti Filho A, Silva AM, Antunes PC, Silva APS, Leite JO. O termo práticas corporais na literatura científica brasileira e sua repercussão no campo da Educação Física. Movimento. 2010; 26(1): 11-29.

10. Geertz C. A interpretação das culturas. Ed. Rio de Janeiro, LTC; 1989.

11. Triviños ANS. Introdução à Pesquisa em Ciências Sociais: a pesquisa qualitativa em educação. 5th edition. Ed. São Paulo, Atlas; 2009.

12. Minayo MCS, editor. Pesquisa social: teoria, método e criatividade. 9th edition. Ed. Petrópolis, Vozes; 1994.

13. Campos CJG. Método de análise de conteúdo: ferramenta para a análise de dados qualitativos no campo da saúde. Rev. bras. enferm. 2004; 57(5): 611-614.

14. Silva SS, Medeiros CCC, Marchi Júnior W. Habitus e prática da dança: uma análise sociológica. Motriz: J. Phys. Ed. 2012; 18(3): 465-475.

15. Campos GWS. Clínica e saúde coletiva compartilhadas: teoria paidéia e reformulação ampliada do trabalho em saúde. In: Campos GWS, Minayo MCS, Akerman M, Drumond Júnior M, Carvalho YM, editors. Tratado de Saúde Coletiva. Ed. São Paulo, Hucitec; 2006. p.53-93

16. Baptista TJR. A educação do corpo na sociedade do capital. Ed.Curitiba, Appris; 2013.

17. Mantovani EP. O importante papel da mídia na adesão à prática de atividade física no envelhecimento. In: Vilarta R, Gutierrez GL, Carvalho THPF, Gonçalves A, editors. Qualidade de vida e novas tecnologias. Ed. Campinas, Ipês; 2007. p.199-206.

18. Figueira Júnior AJ. Potencial da mídia e tecnologias aplicadas no mecanismo de mudança de comportamento, através de programas de intervenção de atividade física. R. Bras. Ci. e Mov. 2000; 8(3): 39-46.

19. Fraga AB. Promoção da vida ativa: nova ordem físico-sanitária na educação dos corpos contemporâneos. In: Bagrichevsky M, Palma A, Estevão A, Da Ros M, editors. A saúde em debate na educação física - volume 2. Ed. Blumenau, Nova Letra; 2006. p.103-118.

20. Herdy AH, López-Jiménez F, Terzic CP, Milani M, Stein R, Carvalho T et al . Diretriz Sul-Americana de Prevenção 
e Reabilitação Cardiovascular. Arq Bras Cardiol. 2014; 103(2Supl.1): 1-31.

21. Kock S, Morlinghaus K, Fuchs T. The joy dance. Specific effects of a single dance intervention on psychiatric patients with depression. Arts in Psychotherapy. 2007; 34(4): 340-349.

22. Carvalho YM, Mendes VM. Corpo \& Cuidado. Ed. São Paulo, Hucitec; 2019.

23. Santos SC, Knijnik JD. Motivos de adesão à prática de atividade física na vida adulta intermediária. Rev. Mackenzie Ed. Física e Esporte. 2006; 5(1): 23-34.

24. Antunes PC, Schneider MD. D. Práticas corporais e a dimensão da sociabilidade: a experiência do subprojeto de pesquisa "Práticas corporais na Maturidade”. In: Falcão JLC, Saraiva MC, editors. Práticas corporais no contexto contemporâneo: (in)tensas experiências. Ed. Florianópolis, Copiart; 2009. p.126-144.

25. Toldrá RC, Cordone RG, Arruda BA, Souto ACF. Promoção de saúde e da qualidade de vida com idosos por meio de práticas corporais. O Mundo da Saúde. 2014; 38(2): 159-168.

26. Domene PA, Moir HJ, Pummell E, Knox A, Easton C. The health enhancing of Zumba ${ }^{\circledR}$ fitness: An 8 week randomised controlled study. J Sports Sci. 2016; 34(15): 1396-404.

27. Pich S. Saberes do/sobre o corpo: governamentalidade, biopolítica e cuidado de si. In: Carvalho YM, Fraga AB, Gomes IM, editors. As práticas corporais no campo da saúde. v.3. Ed. São Paulo, Hucitec; 2016. p.154-171.

28. Peto AC. Terapia através da dança com laringectomizados: relato de experiência. Rev. Latino-Am. Enfermagem. 2000; 8(6): 35-39.
29. Abrão ACP, Pedrão LJ. A contribuição da dança do ventre para a educação corporal, saúde física e mental de mulheres que frequentam uma academia de ginástica e dança. Rev. Latino-Am. Enfermagem. 2005; 13(2): 243-248.

30. Matos JAV. Práticas corporais: o corpo cidadão como expressão da promoção da saúde. Belo Horizonte. Tese [Doutorado em Enfermagem]. Escola de Enfermagem da Universidade Federal de Minas Gerais; 2019.

\section{Corresponding author}

Rogério Cruz de Oliveira.

Universidade Federal de São Paulo - Campus Baixada Santista, Departamento de Ciências do Movimento Humano, Rua Silva Jardim 136, Cep: 11015-020, Santos,SP, Brazil. Telephone: +55 (13) 3229-0275

Email: rogerio.cruz@unifesp.br

Manuscript received on September 11, 2020.

Manuscript accepted on October 5, 2020.

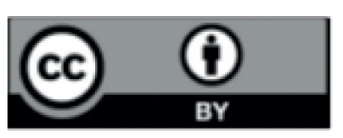

Motriz. The Journal of Physical Education. UNESP. Rio Claro, SP, Brazil - eISSN: 1980-6574 - under a license Creative Commons - Version 4.0 


\section{Erratum}

In the article “Reasons for women's approach and permanence in Zumba”, published in volume 26, number 4, 2020: DOI: http://dx.doi.org/10.1590/S1980-65742020000400126 and identification e10200126.

In the Figure 2:

Where it reads: 1 [VALOR], $6 \%$.

Should be: $18,6 \%$

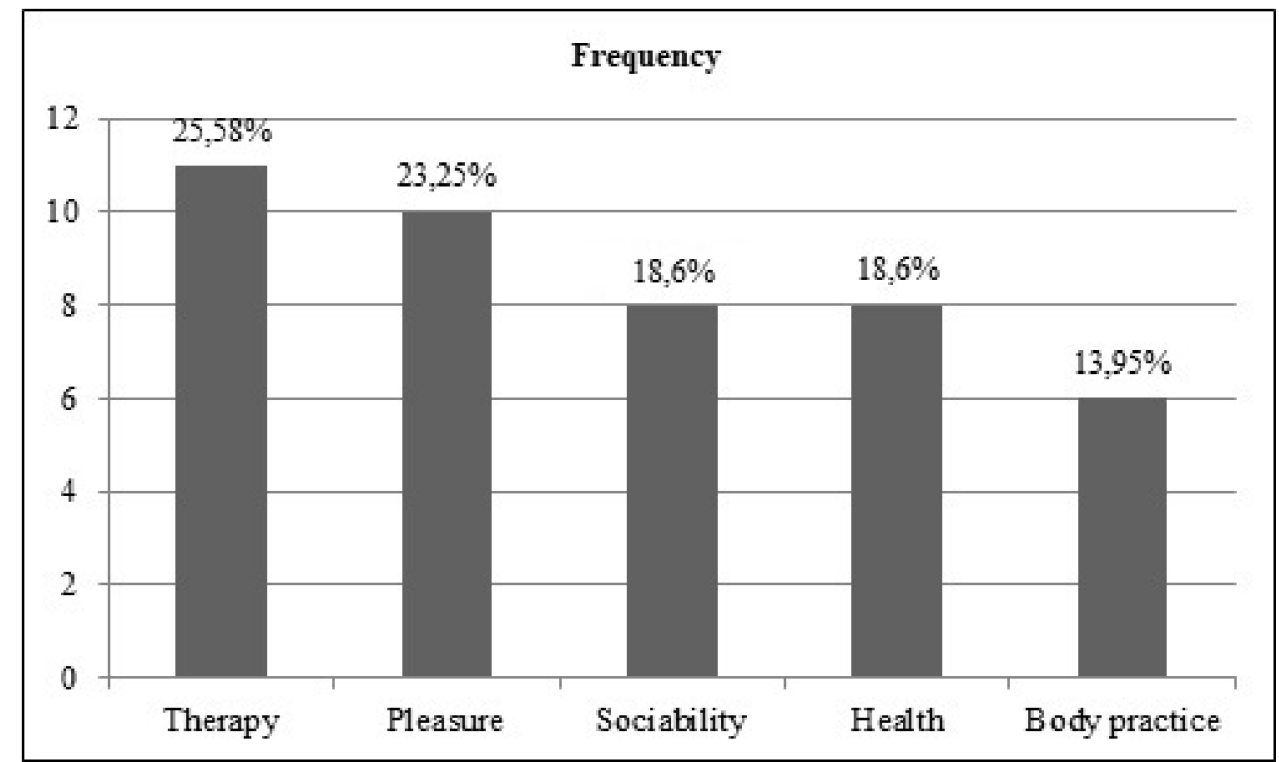

